\title{
Hydroids (Cnidaria, Hydrozoa) of Coral Reefs: Preliminary Results on Community Structure, Species Distribution and Reproductive Biology in Juan de Nova Island (Southwest Indian Ocean)
}

\author{
Nicole GRAVIER-BONNET and Chloé A-F BOURMAUD \\ Laboratoire d'Ecologie Marine, Faculté des Sciences et Technologies, Université de La Réunion, 15 Av. \\ René Cassin, BP 7151, 97715 Saint-Denis Messag Cedex 9, La Réunion, France
}

Key words: Hydrozoa, coral reefs, species richness, distribution, reproductive biology, Indian Ocean

\begin{abstract}
The first field investigation of the marine life at Juan de Nova gave an opportunity to study hydroid diversity in April-May 2004. Species richness was high, with 95 species belonging to 26 families and 44 genera. Thecates dominated $(72 \%)$, with three families particularly diverse: Haleciidae, Sertulariidae and Aglaopheniidae. There were four different sub-communities with a few species in common: two intertidal and two subtidal. One was located on reef flats subject to strong hydrodynamic conditions, and included rheophilic and photophilic species such as Millepora exaesa, Nemalecium sp., Dynamena crisoides, Thyroscyphus fruticosus, Thyroscyphus sp. and Aglaophenia cupressina. The second was found where the reef flat experienced calmer conditions, and comprised mainly Plumularioidea and Haleciidae species with small sized colonies $(1-3 \mathrm{~cm})$ and large populations, densely covering the hard substrata of coral patches. The third sub-community colonized the reef platform (5$20 \mathrm{~m})$, with hydroids widespread and diverse. The fourth was on the outer slope, deeper $(30 \mathrm{~m})$, and was characterized by the presence of four Solanderia species, several Aglaophenids and Thyroscyphus aequalis. Most of the species were brooders (84\%). Present data are discussed regarding environmental parameters, and compared with data from the fles Glorieuses, other islands of the Mozambique Channel.
\end{abstract}

\section{INTRODUCTION}

Hydroids have been considered an important component of coral reef fauna only recently. In fact, whereas taxonomical works are published on scattered specimens, often incorporated into larger collections (South Africa: Millard, 1975, 1978; New Zealand: Schuchert, 1996), extensive studies done with the aim to estimate hydroid species richness of a coral reef, and to describe the species distribution pattern, are rare. Nonetheless, some studies have provided data from the Atlantic: Bermudas (Calder, 1988, 1991, 1993, 1997, 1998),
Brazil (Migotto, 1996), Carribbean (Vervoort, 1968; Mergner, 1977), Jamaica (Mergner, 1972), Puerto Rico and Virgin Islands (Wedler \& Larson, 1986); the Pacific: Australia (Pennycuik, 1959), Bonin islands (Hirohito, 1974), Fiji (Gibbons \& Ryland, 1989), French Polynesia (Rédier, 1971; Vervoort \& Vasseur, 1977), Hawaï (Cooke, 1977), New-Caledonia (Rédier, 1966) and the Red Sea (Mergner \& Wedler, 1977; Mergner, 1977). For the Indian Ocean, research has been conducted off West Australia (Watson, 1996, 1997), India (Mammen, 1963, 1965a, 1965b), and the south west part of the Indian Ocean (see review by 
Gravier-Bonnet \& Bourmaud, 2006). Though this list of references is not exhaustive, our present knowledge is sparse considering the small size of the areas investigated compared to the worldwide distribution of coral reefs. In addition, some data are available for pelagic hydromedusae collected from the water column, presumed to belong to local benthic hydroids, e.g. for Papua New Guinea (Bouillon, 1978, 1980, 1984).

This paper is the first report for the island of Juan de Nova, one of the five French "Îles Eparses", including the islands Tromelin, Glorieuses, Juan de Nova, Bassas da India and Europa. Juan de Nova is located at $17^{\circ} 03^{\prime} \mathrm{S}$ and $42^{\circ} 43^{\prime} \mathrm{E}$ where the Mozambique Channel is narrowest, at $175 \mathrm{~km}$ from the coast of Madagascar and $285 \mathrm{~km}$ from Africa. The island has a maximum length and width of $6 \mathrm{~km}$ and $1.6 \mathrm{~km}$ respectively and it is of about $5 \mathrm{~km}^{2}$ in area (Fig. 1). It is located on an oceanic reef of about 200

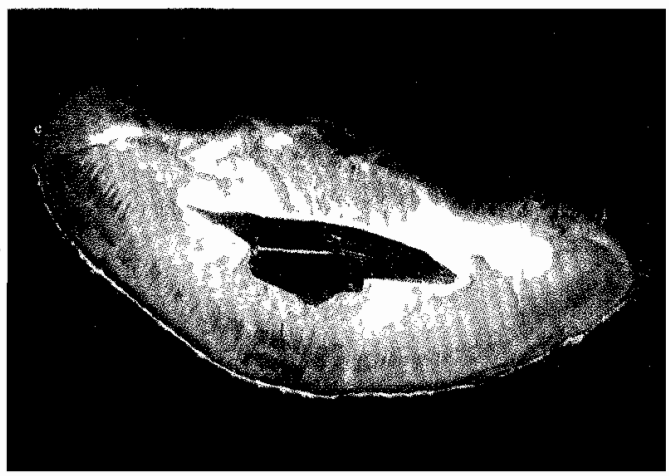

Fig. 1. The island Juan de Nova (maximum width $6 \mathrm{~km}$ ), surrounded by the coral reef flats emerging at spring tides; the wide and deeper platform extending to the north is not visible on the picture (satellite image, Shuttle)

$\mathrm{km}^{2}$ inside the $20 \mathrm{~m}$ isobath, and includes a submersed platform that extends north for a distance of about $17 \mathrm{~km}$ from the island. The main reef front is on the south as a result of the dominant winds, currents and swells in the Mozambique Channel, with a very steep outer slope. The land is flat and consists mainly of a fossil coral reef of a karstic structure with sand dunes. Two breeding colonies of sooty sterns Sterna fuscata Linnaeus, 1766 , of 2,000,000 pairs, the largest population in the Mozambique Channel, are present on the eastern and western tips of the island during the austral summer, nesting in November-December (Le Corre \& Jacquemet, 2005). They are the origin of a phosphate deposit that was exploited during the last century up until 1972. Currently, the island is not exposed to anthropic pressures, as the only permanent occupation is a small military group enforcing the protected status of the area.

The development of a French research program on the marine biodiversity of the "Îles Eparses", associated with filming for a TV movie, recently facilitated the first study on the marine environment and biodiversity at Juan de Nova lsland (ARVAM, 2004). Preliminary results, dealing with hydrozoan community structure, species distribution and reproductive biology, are described in this paper (a detailed taxonomic study will be undertaken later on the collections). They will be compared with results obtained recently in the Îles Glorieuses, located further to the north of Madagascar (Gravier-Bonnet \& Bourmaud, 2006).

\section{MATERIALS AND METHODS}

Studies were done during one field trip organized by Tec-Tec Production during the austral interseason, from summer to winter (27 April-17 May 2004). Field investigations involved exploration of reef flats, reef platform and outer slope by either snorkeling or scuba diving to manually collect macroscopic specimens of benthic hydroids as well as macroscopic algae (well-known suitable substrata for microscopic species). A total of 35 stations were sampled, all registered by GPS Twenty-one stations were located on the wide tidal reef flat, accessible during low tide on foot, and 14 stations were sampled using scuba-diving, with six located on the reef platform and eight on the outer reef slope on three sites (Fig. 2). Photographs were taken in situ.

Laboratory studies were undertaken on the samples soon after collection. Living colonies were sorted and observed under a stereo-microscope. Several characteristics were checked (e.g. colour, state of fertility, associated organisms). Specimens were fixed in $4 \%$ formaldehyde in seawater and some preserved in alcohol for further identification and genetic analysis. 


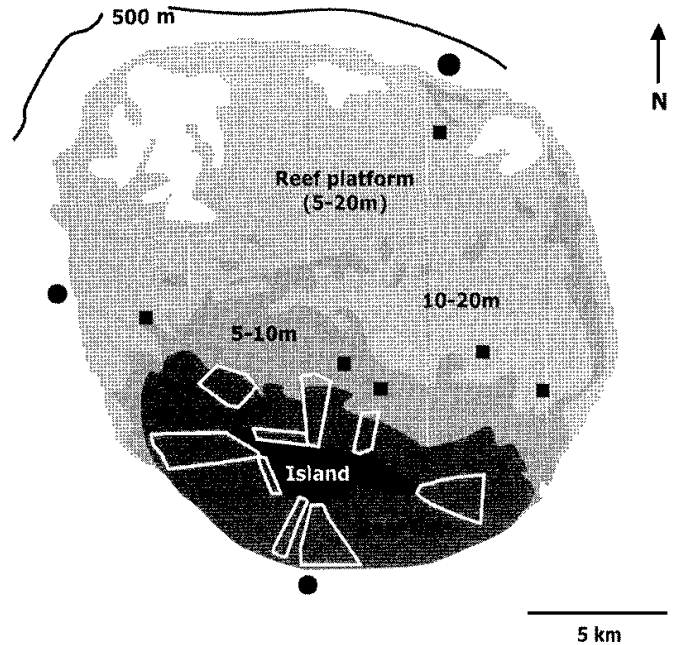

Fig. 2. Location of sampling areas around Juan de Nova island: areas of the reef flat investigated by foot and snorkeling (delimited with white lines), diving stations on the reef platform (quadrate dots) and diving sites on the outer slope (rounded dots)

Macrorhynchia spectabilis (Allman, 1883), a species placed in the synonymy with Macrorhynchia phoenicea (Busk, 1852), was recently restored to a species following the study of living specimens from the îles Glorieuses (see Gravier-Bonnet \& Bourmaud, 2006). Sertularella delicata Billard, 1919, given later as a variety of Sertularella diaphana (Allman, 1885) by Billard himself (1925), was considered here as a species from the study of fertile living specimens collected at La Réunion (Gravier-Bonnet, unpublished data).

\section{RESULTS}

\section{Species richness and community structure}

Among the 291 specimens collected, a total of 95 species was distinguished but with only one third precisely determined up to now. They belong to at least 26 families and 44 genera, with a larger number of thecate species ( $72 \%$ ) than of athecates (Table 1).

There were up to six species per family, except for the Aglaopheniidae (19 species), the Sertulariidae (12 species) and the Haleciidae (ten species). Genera with the most species (4 to 6) were
Table 1. Distribution of the numbers of species, genera and families

\begin{tabular}{lccc}
\hline & Families & Genera & Species \\
\hline Athecates & 13 & 18 & 27 \\
Thecates & 13 & 26 & 68 \\
TOTAL & 26 & 44 & 95 \\
\hline
\end{tabular}

Eudendrium and Solanderia for the Athecates, Halecium, Nemalecium, Dynamena, Antennella, Plumularia, Gymnangium, Lytocarpia and Macrorhynchia for the Thecates.

Most of the species collected were microscopic or small sized $(<2 \mathrm{~cm})$, growing either on algae, other hydroids, or on natural hard substrates. Species of larger size were found exclusively among two athecate families (Solanderiidae and Milleporidae) and five thecate families (Haleciidae, Sertulariidae, Thyroscyphidae, Plumulariidae and Aglaopheniidae).

\section{Species distribution and biology}

Overall, 42 species were collected from the intertidal and 75 were collected in the subtidal. Four sub-communities were separated in relation to different environmental conditions prevailing in the area investigated (two intertidal, and two subtidal). The first sub-community was intertidal and was encountered in the east, south and west, where the reef flats were exposed to the main water mass regime from the south of the Mozambique Channel, and submitted to strong currents and swells. The second intertidal sub-community inhabited the reef flats of the north where waters were calmer due to shelter from the main currents prevalent at the ends of the island. Exposed and sheltered reef flats emerged at low tides. The third sub-community was subtidal and found deeper than the two previous though less than $20 \mathrm{~m}$, and was situated on the reef platform to the north. The fourth sub-community inhabited the outer slope at $30 \mathrm{~m}$ depth. The four sub-communities included four species in common (4\%): Nemalecium lighti (Hargitt, 1904), Nemalecium sp., Halopteris sp. 1 and Halopteris sp. 2.

The percentages of species common and specific according to levels are illustrated in Figure 
3 , with $21 \%$ common to both intertidal and subtidal stations, $7 \%$ common only to the intertidal, $14 \%$ at both subtidal stations, and the others were species exclusive to a single sub-community, being $7 \%$ for the exposed reef flat, $11 \%$ for the sheltered reef flat, $12 \%$ for the subtidal platform and $28 \%$ for the subtidal outer slope. Of the whole collection, $25 \%$ were specific of intertidal habitats, whereas $54 \%$ of the species were found only in the deeper waters. endoderm. Dynamena crisioides Lamouroux, 1824 , a smaller species colonizing hard substrates and supporting emersion, was a characteristic species of this sub-community that was found also growing on ancient cannons lying on the front of the reef, originating from ship wrecks (Fig. 4b). Three other macroscopic species, common with the other sub-communities, were present: Thyroscyphus fruticosus and Thyroscyphus sp.

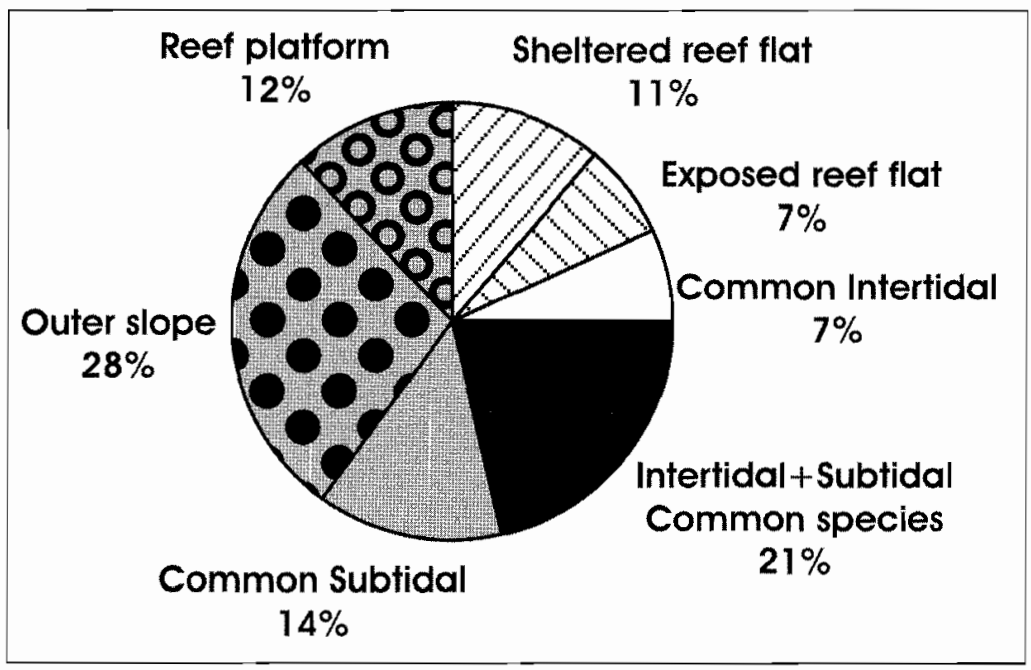

Fig. 3. Ecological distribution of the species belonging to intertidal (white) and subtidal (grey), with common species to both level (black) and percentages for common (uniform) and exclusive (striped for the two intertidal and dotted for the two subtidal) species of the different sub-communities

The exposed reef flat (east, south and west intertidal)

This area exhibited large sandy areas with coral patches more or less covered by sand resulting in a low percentage of hard coral coverage. In several locations, coral cover was greater, and in others big sponges were very abundant. The subcommunity of hydroids of the exposed reef flat comprised 29 species forming scattered colonies, mainly photophilic and rheophilic. The most abundant were the firecoral Millepora exaesa Forskal, 1875, and the fireweed Aglaophenia cupressina Lamouroux, 1816, an Indo-Pacific species also present on the sheltered reef flat (Fig. $4 d$ ). It exhibited a frond-like shape, with uprights 'fronds' of $15-30 \mathrm{~cm}$ length, growing in clumps on hard substrata, among hard and soft corals, sponges and seaweeds, and a yellow-brown colour due to the presence of zooxanthellae in the
(Fig. 4a) growing both on hard bottom (but the second also found fixed on sponges), and Nemalecium sp., colonizing walls and tips of large grey sponges (Fig, 4c). Smaller species were semicryptic, inhabiting cavities and overhangs of the coral patches, or between blades of the brown seaweed Turbinaria ornata (Turner) J. Agardh, examples including Kirchenpaueria irregularis (Millard, 1958). and species of Eudendrium, Halecium, Halopteris and Antennella.

\section{The sheltered reef flat (northern intertidal)}

In between the two large sandy areas of the extremities of the island, the sheltered reef flat in the north exhibited large and compact zones, with living corals and algae, and scattered coral patches of varied sizes, immersed into the shallow waters of the reef platform. The second hydroid 

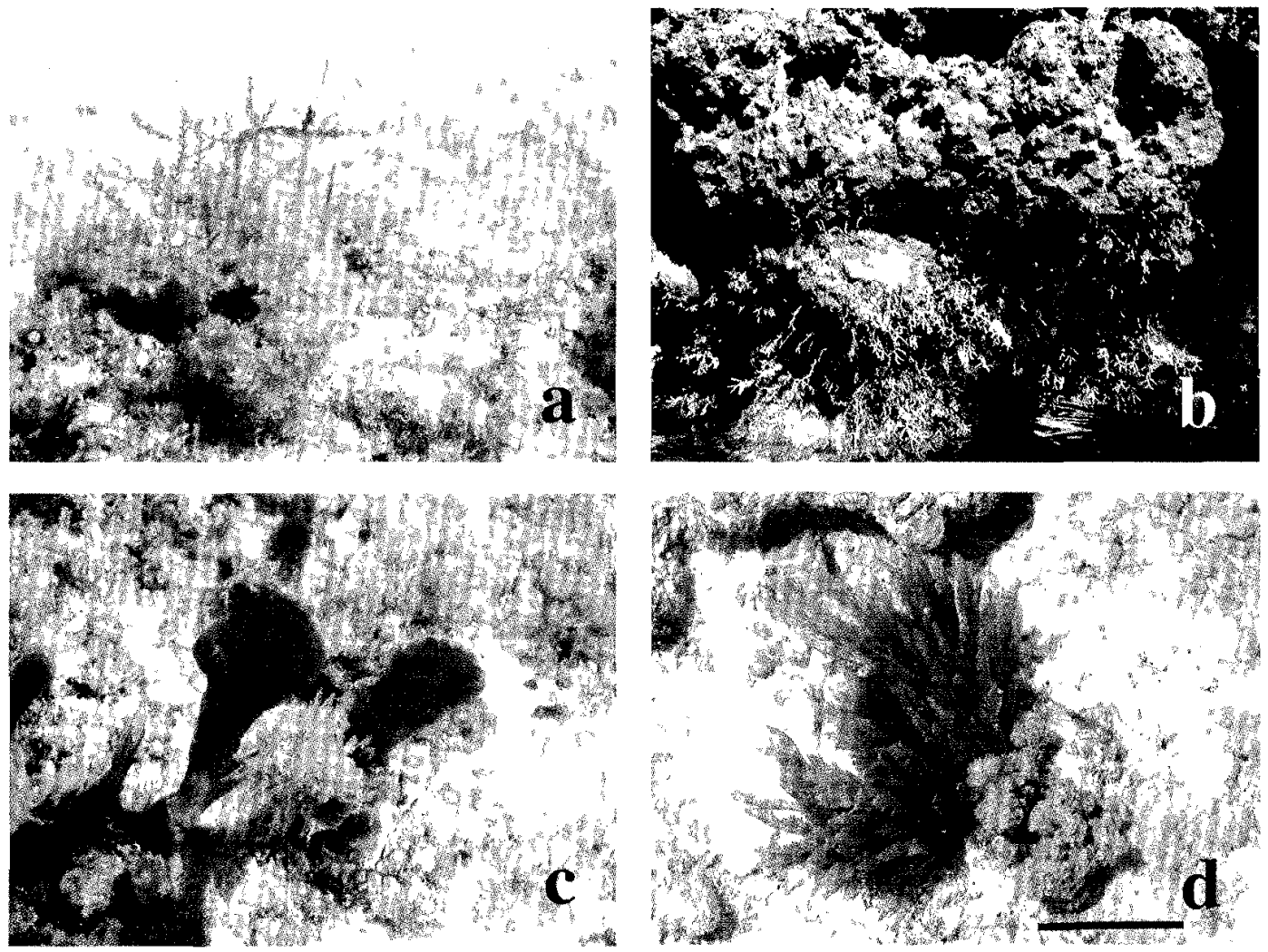

Fig. 4. Hydroids of the Juan de Nova coral reef: colonies of macroscopic intertidal species of the exposed reef flat. (a) Thyroscyphus sp. on hard substrata, with brown algae Turbinaria ornata, (b) Dynamena crisioides on the side on a big cannon, (c) Nemalecium sp. on tip of grey sponges, (d) Aglaophenia cupressina on hard bottom. All numeric photographs taken in situ, (by Nicole Gravier-Bonnet), at low tide. Scale bar: (a, d) $4 \mathrm{~cm}$, (b) $1 \mathrm{~cm}$, (c) $2 \mathrm{~cm}$

community there included 31 species. It was composed of photophilic species, as $A$. cupressina and $M$. exaesa and of a lot of small species that formed dense and mixed populations on hard substrates and on algae (mainly on the green algae Halimeda spp.), such as Eudendrium sp., Nemalecium lighti, Nemalecium sp., K. irregularis, Antennella sp., Halopteris sp., Plumularia warreni Stechow, 1919 and Plumularia strictocarpa Pictet, 1893. In addition, several others were semi-cryptic, as Macrorhynchia sp. and Gymnangium sp. Moreover, Cytaeis nassa (Millard, 1959) was found at low tide, during the night, on the shell of the sandy bottom gastropod Nassarius plicatellus (Adams, 1852). Among these small species, four were characteristic of the sheltered reef flat, and abundant: Plumularia strictocarpa, P. warreni, Gymnangium sp. and Macrorhynchia sp.

\section{The reef platform $(<20 \mathrm{~m})$}

On the reef platform the coverage by living corals was very low. At several locations, hard corals were dead and overgrown by a number of Halimeda species and cyanobacteria. However, where living hard corals existed, the small hydroid species $N$. lighti was found several times, usually inside crevices. In locations where the benthic fauna was healthy, hydroids were more abundant leading to the high species richness in such habitats (41 species). Small colonies were usually growing on living substrates (such as red algae, ascidians, sponges or gorgonians) e.g. Pteroclava ?krempfi Billard, 1919 on gorgonians, or directly on the sea bed, such as Eudendrium spp., Synthecium samauense Billard, 1924 and Halopteris spp. Large colonies were also attached directly to the substratum, including four Solanderia species, 
Pennaria disticha Goldfuss, 1820, Macrorhynchia philippina Kirchenpauer, 1872, Gymnangium hians (Busk, 1852) and Lytocarpia brevirostris (Busk, 1852). Several species were exclusively of this sub-community, for example Plumularia setacea (Linnaeus, 1758), Aglaophenia postdentata Billard, 1913, Dynamena crisioides Lamouroux, 1824, var. gigantea Billard, 1925, and other as yet unidentified species of the genera Eudendrium, Clytia, Hydrodendron and Sertularella. Eighteen species, of which nine were not collected elsewhere, were found on a metal wreck located at $10 \mathrm{~m}$ depth to the northwest of the island.

\section{The outer slope $(30 \mathrm{~m})$}

On the outer slope, divers registered a large amount of dead hard corals, likewise the reef platform, except at the station located in the west. However, the fourth hydroid sub-community was the most diverse, with a total of 58 species collected from hard substrata, on algae or on sessile benthic invertebrates. It was mainly characterized by the frequency of the four Solanderia species previously recorded on the platform, together with the presence of a large number of aglaophenids (16 species), of which ten were specific to this level, like Gymnangium ferlusi Billard (1901), Macrorhynchia filamentosa (Lamarck, 1816), Macrorhynchia spectabilis (Allman, 1883), and Lytocarpia flexuosa (Lamouroux, 1816). Other characteristic species not found elsewhere were Sertularella delicata Billard, 1919, Thyroscyphus aequalis Warren, 1908, and the two stylasterids Distichopora violacea (Pallas, 1766) and Stylaster sp. Several species were present both on the outer slope and on the platform, such as $S$. samauense, Diphasia heurteli Billard, 1924, L. brevirostris, $M$. philippina, G. hians, and Gymnangium gracilicaule (Jäderholm, 1903).

\section{DISCUSSION}

\section{Species richness, and community structure}

The species richness of the hydroid fauna of the small island of Juan de Nova is high compared with other much larger locations of the tropics (GravierBonnet \& Bourmaud, 2006). This could be the result, or combination, of two factors. Firstly, the geographical position if the island in the middle of the Mozambique Channel where the water masses undergo oceanic gyrs emanating both from the South Equatorial Current to the north and from the south of the Mozambique Channel (see Jaquemet, 2005, after Schott \& Mc Creary, 2001) which probably transports organisms and larvae from both Africa and Madagascar, thus influencing the composition of the marine fauna. Secondly, the peculiar features of the shallow waters surroundings the island, including the omnipresence of very fine sediment in suspension due to the breakdown of the calcareous green algae Halimeda combined with water enrichment from nutrients derived from the defecation of the large sea bird population inhabiting the island several months a year. The leaching of guano and phosphates all year round is likely to enhance the growth of Halimeda and of several cyanophytes present everywhere in great abundance, even on hydroid colonies. Though the number of hydroid species collected is high, the true species richness is unlikely to have been recorded during this preliminary study because of an insufficient number of samples. Evidence for this includes (i) the fact that at every subtidal station new samples provided additional species, (ii) parts of the reef flats located far from the island were not sampled, and (iii) a part of the microscopic material in the collection was not considered in this preliminary study.

The proportion of Athecate species (29\%) compared to Thecates species was found to be in the usual range (26-30\%) for benthic polyps in tropical areas (Gravier-Bonnet \& Bourmaud, 2006). The predominance of the families Sertulariidae and Aglaopheniidae in numbers of species is noteworthy and agrees with community structure in La Réunion and the Îles Glorieuses (see below). The predominance of the family Haleciidae is original and questioned about peculiarly suitable environmental conditions, even leading to radiation, for the genus Nemalecium for example. The absence of diversification for the genus Millepora has also to be noted since in most of the western Indian Ocean, several species are 
usually found together, as for Madagascar (Pichon, 1978) and the Mascarene Islands (Bouchon, 1981; Faure, 1982), or for Mahé Island in the Seychelles (Hoeksema \& Borel Best, 1994). Conversely, the genus Solanderia is well represented.

\section{Species distribution}

Comparison between the four sub-communities highlights their heterogenic features as being probably related to the variety of habitats and environmental conditions (Fig. 3 \& 5). First, there were only four species common to all four subcommunities (representing $4 \%$ of the total number). Second, the percentage of species exclusive to each sub-community was conspicuous, increasing gradually with depth from the exposed reef flat (7\%) to the outer slope $(28 \%)$, following the increase in species richness from 29 to 58. The greater species richness of the outer slope, as well as the increasing of species richness with depth, has been previously noted for coral reefs at La Réunion (Gravier-Bonnet, 1985) and the Îles Glorieuses (Gravier-Bonnet \& Bourmaud, 2006).
A small percentage of the total species $(21 \%)$ were common to both the intertidal and subtidal habitats, while the two intertidal sub-communities exhibited $33 \%$ of species in common (14/42), and the two subtidal sub-communities shared $32 \%$ of species $(24 / 75)$. With respect to the outer slope, only $7 \%$ of the species were common to the south, north, and west, reflecting the species richness of this environment and raising questions about the heterogeneity even within a sub-level, though such comparisons should be taken with caution because they could partly result from differences in the collection methods and in the number of stations in the different locations.

\section{Reproductive biology}

From generic diagnoses based on current knowledge of hydroids, it can be estimated that, at Juan de Nova, the hydroid fauna was characterized by a large majority of species ( $84 \%$ ) without medusa in the life cycle. This is due to a large number of species ( $67 \%$ of the total) belonging to families where the medusa is absent: the Solanderidae and Eudendriidae for athecates $(10 \%)$

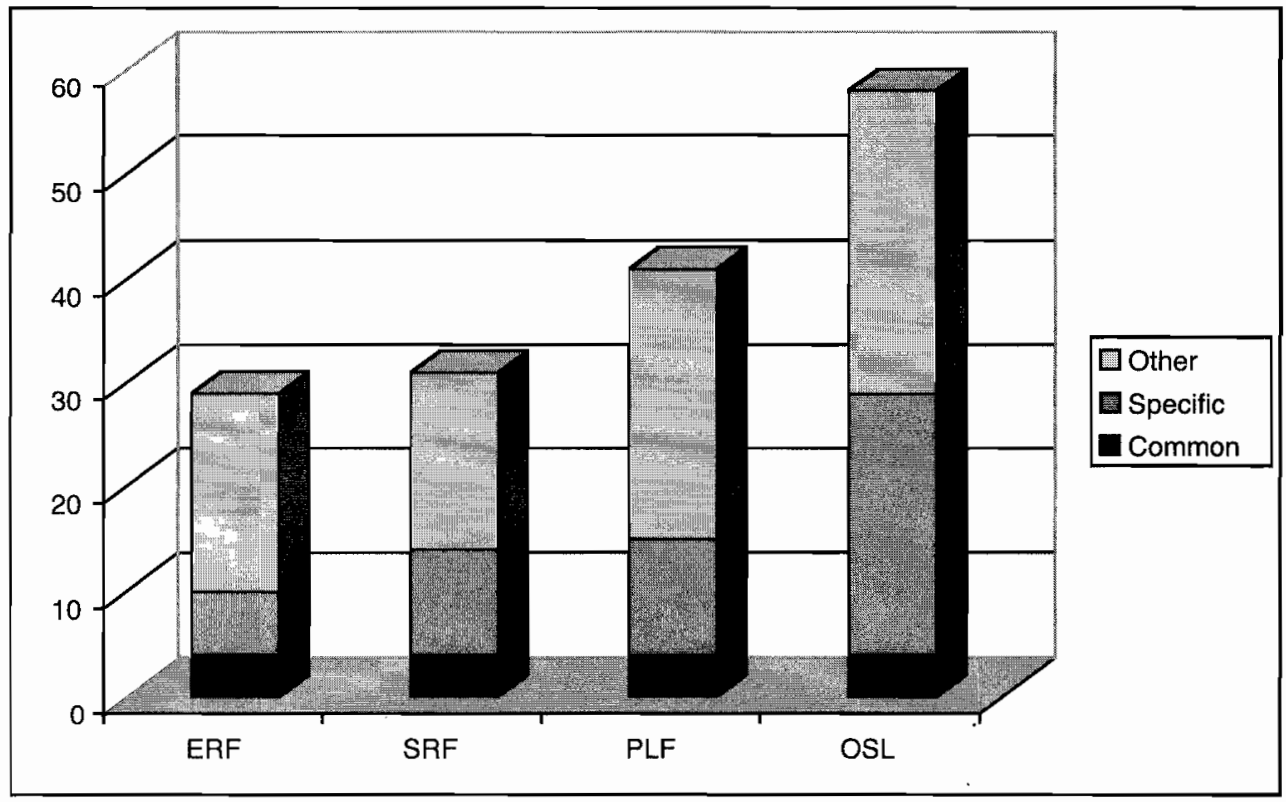

Fig. 5. Comparison of relative species richness between the four sub-communities (ERF, exposed reef flat; SRF, sheltered reef flat; PLF, platform; OSL, outer slope): each column representing the number of species of a single subcommunity is divided in three parts, species common to the four sub-communities (black), specific to the subcommunity (dark grey), and other, that can be common to two or three (light grey) 
and the Haleciidae, Sertulariidae, Halopteriidae, Plumulariidae and Aglaopheniidae for the thecates $(57 \%)$. In these families, the medusa stage is considered to have been lost during evolution: the polyp colony, comprising fixed gonophores, secures the sexual reproduction in releasing in the water either planula larvae ready to settle (for brooders) or gametes (for broadcast spawners). Meanwhile, an intermediary process was described for some species belonging to these evolved families: the budding of short-lived medusoids able to disperse around the gametes, when sexual maturity is achieved, leading to the formation of planulae in the water near the mother colony (see Bourmaud \& Gravier-Bonnet, 2004 for a review). At Juan de Nova, $67 \%$ of the species collected were with fixed gonophores (mainly brooders), 17\% were medusoid-releasing species and $16 \%$ reproduced via a medusa. Such a situation reflects that already found in other remote islands (Cornelius, 1992), like for example La Réunion and the Îles Glorieuses (full discussion in GravierBonnet \& Bourmaud, 2006).

\section{Comparison with the îles Glorieuses}

A previous study undertaken in the Îles Glorieuses proposed a name for these islands as a "hydroid paradise" (Gravier-Bonnet \& Bourmaud, 2006). This view had not changed after the present study. The hydroid fauna at Juan de Nova was less abundant and visibly not so obviously prolific, probably because of smaller colony and population sizes. Both islands however exhibited high species richness, even slightly higher for Juan de Nova (95) than for Glorieuses (88). Fish species richness was also high (299 and 333) on these small isolated islands of the westward region of the Indo-Pacific (Durville et al., 2003; Chabanet \& Durville, 2005). For hard corals, 92 and 69 species were recorded respectively (ARVAM, 2002-2003, 2004). It is well-known that the 1998 El Nino event provoked an important rising of the temperature during several months from the south of the Mozambique Channel to the Seychelles, resulting in a'high mortality rate in hard corals. Consequently the coral coverage was still low a few years later, at the time of the present study, probably providing more substrata than usual available for hydroid settlement on coral reefs. Whether this has really increased species richness or population size is unknown.

The comparison of hydroid species lists, in the present state of the study, shows that 23 of the wellidentified species of Juan de Nova were not found in the Îles Glorieuses, and that only 29 species (31.5\%) were common to the two islands despite their relative proximity. The differences registered could be explained by different oceanic conditions, with the Îles Glorieuses directly and solely exposed to the influence of the South Equatorial Current, whereas Juan de Nova is in a more complex hydrographic zone (Jacquemet, 2005). However, although having only $1 / 3$ of species in common with the Îles Glorieuses, it has to be noted that the structure of the hydroid community at Juan de Nova was very similar, the same families being present with about equal numbers of species. Slight differences are however obvious for the families Haleciidae, Sertulariidae and Aglaopheniidae, the first and third being much more speciose in Juan de Nova compared to the second. Several genera also differed. For example, one of the most interesting was the genus Nemalecium for which a radiation process is suspected, but which needs additional morphologic and genetic study. Indeed, instead of the single species $N$. lighti in the Îles Glorieuses, there are probably several species in Juan de Nova. Other differences were registered for species common to the two islands and similarly distributed but lacking the same importance within the ecosystem, even if the geomorphology (e.g. general structure, age of the islands) and the abiotic environment (oceanic reef) appear similar. The most unexpected example was the rarity of $D$. crisioides at Juan de Nova whereas this species was abundant on all intertidal hard substrata of the Îles Glorieuses. In the same way, scattered colonies of $M$. spectabilis were present on the outer slope in place of forming large populations, and even $A$. cupressina was also less abundant in shallow waters. In the deeper zones, the genus Zygophylax (lafoeid) was absent as well. Furthermore, an important observation was the total absence of seagrass beds in Juan de Nova, with the whole specific associated hydroid fauna. A single 
specimen of Thalassodendron ciliatum (Forskål) den Hartog, bearing an epiphytic colony of a Sertularid species on leaves, was collected on the sandy beach, in the south of the island, probably having been carried by water currents from the coast of Madagascar. This sertularid species was not taken into account in this study because of its suspected foreign origin.

In conclusion, we can say that the results of the present study, though preliminary, significantly enlarge our general knowledge on hydroids of coral reefs and therefore on coral reef biodiversity in the Indian Ocean. They confirm (i) the high species richness of the hydroid fauna in the western area, even in small and isolated islands, (ii) the presence of varied groups of species distributing differently according to depth and to environmental abiotic parameters, and (iii) the importance of the outer slope as the most speciose compartment of coral reefs for benthic hydroids.

Acknowledgements-We are very grateful to our colleague Pascale Chabanet who invited us to participate to this wonderful adventure in Juan de Nova, and to Rémy Tézier who imagined and realized it. Many thanks to Tec-Tec Production that provided funds, to R. Tézier's team who organized the field trip and provided diving features and security, to "Forces Armées de la Zone Sud de l'Océan Indien" for accommodations, and to "Préfecture de la Réunion" for authorisations. We are especially indebted with Eric Hoarau, Martine Fournier and Patrick Durville, our main providers of subtidal specimens, and to Arvam team, JeanPascal Quod and Rémi Garnier, for underwater photographs. This work was a contribution to the COSURECO Îles Eparses/IFRECOR action plan. Researches on hydroids were supported by the "Conseil Régional de la Réunion".

\section{REFERENCES}

ARVAM (2002-2003) Connaissance et suivi des récifs coralliens des îles françaises de l'Océan Indien (CORUSECO). Plan d'action Îles Eparses Diren/ Ifrecor. Annual technical report (2002-2003), in french, $81 \mathrm{pp}$.

ARVAM (2004) Connaissance et suivi des récifs coralliens des îles françaises de l'Océan Indien (CORUSECO). Plan d'action ̂̂les Eparses Diren/
Ifrecor. Annual technical report (2004), in french, $56 \mathrm{pp}$.

Bouchon, C. (1981) Quantitative study of the scleractinian coral communities of a fringing reef of Réunion Island (Indian Ocean). Mar. Ecol. Prog. Ser. 4: 273-288.

Bouillon, J. (1978) Hydroméduses de la mer de Bismarck (Papouasie, Nouvelle-Guinée). 1 Anthomedusae Capitata (Hydrozoa-Cnidaria). Cah. Biol. Mar. 19(3): 249-297.

Bouillon, J. (1980) Hydroméduses de la mer de Bismarck (Papouasie, Nouvelle-Guinée). 3 Anthomedusae Filifera (Hydrozoa-Cnidaria). Cah. Biol. Mar. 21: 307-344.

Bouillon, J. (1984) Hydroméduses de la mer de Bismarck (Papouasie, Nouvelle-Guinée). 4 Leptomedusae (Hydrozoa-Cnidaria). IndoMalayan Zool. 1: 25-112.

Bourmaud, C. \& Gravier-Bonnet, N. (2004) Medusoids release and spawning in the life cycle of Macrorynchia philippina Kirchenpauer, 1872 (Cnidaria, Hydrozoa, Aglaopheniidae). Hydrobiologia 530/531: 199-208.

Calder, D.R. (1988) Shallow-Water Hydroids of Bermuda. The Athecatae. Life Sci. Cont. Royal Ontario Museum 148: 1. 107.

Calder, D.R. (1991) Shallow-Water Hydroids of Bermuda. The Thecatae, Exclusive of Plumularioidea. Life Sci. Cont. Royal Ontario Museum 154: 1-140.

Calder, D.R. (1993) Local distribution and biogeography of the Hydroids (Cnidaria) of Bermuda. Caribbean J. Sci. 29(1-2): 61-74.

Calder, D.R. (1997) Shallow-Water Hydroids of Bermuda: (Superfamily Plumularioidea). Life Sci. Cont. Royal Ontario Museum 161: 1-85.

Calder D.R. (1998) Hydroid diversity and species composition along a gradient from shallow waters to deep sea around Bermuda. Deep-Sea Res. 45: $1843-1860$.

Chabanet, P. \& Durville, P. (2005) Reef fish inventory of Juan de Nova's natural park (western Indian Ocean). Western Indian Ocean J. Mar. Sci. 4(2): 145-162.

Cooke, W.J. (1977) Reef and shore fauna of Hawaï. Section 1: Protozoa trough Ctenophora. Bernice P. Bishop Museum, Spec. Publ. 64(1):70-104.

Cornelius, P.F.S. (1992) Medusa loss in leptolid Hydrozoa (Cnidaria), hydroid rafting, and abbreviated life-cycles among their remote-island faunae: an interim review. Sci. Mar. 56(2-3): 245261.

Durville, P., Chabanet, P. \& Quod, J-P. (2003) Visual census of the reef fishes in the natural reserve of the Glorieuses islands (western Indian Ocean). Western Indian Ocean J. Mar. Sci. 2: 95-104. 
Faure, G. (1982) Recherche sur les peuplements de Scléractinaires des récifs coralliens des Mascareignes (Océan Indien occidental). Thèse es sciences, Université Aix-Marseille II, 206pp. \& annexes.

Gibbons, M. J. \& Ryland, J. S. (1989) Intertidal and shallow water hydroids from Fiji. I. Athecata to Sertulariidae. Mem. Queensl. Mus. 27(2): 377-432.

Gravier-Bonnet, N. (1985) Hydroids in coral reefs of Réunion Island. Proceed. 5th Intern. Coral Reef Congress, Tahiti 2: 155.

Gravier-Bonnet, N. \& Bourmaud, C. (2006) Hydroids (Cnidaria, Hydrozoa) of coral reefs: preliminary results on community structure, species distribution and reproductive biology in the Îles Glorieuses (southwest Indian Ocean). Proceed. 10th ICRS, Okinawa, Japan, 2004, pp. 188-196.

Hirohito, 1974. Some Hydrozoans of the Bonin Islands. Publs biol. Lab., Imp. Household, Tokyo 1974 (11), 55 pp.

Hoeksema, B.W. \& Borel Best, M. (1994) Stony reef corals. In J, van der Land, Oceanic Reefs of the Seychelles, Netherland Indian Ocean Programme, Cruise Reports 2: 81-91.

Jacquemet, S. (2005) Rôle des oiseaux marins tropicaux dans les réseaux trophiques hauturiers du sud-ouest de l'océan Indien. Thèse d'Océanologie biologique, Université de la Réunion, 162pp.

Le Corre, M. \& Jacquemet, S. (2005) Assessment of the seabird community of the Mozambique Channel and its potential use as an indicator of tuna abundance. Estuarine Coastal and Shelf Science 63: 421-428.

Mammen, T.A. (1963) On a collection of Hydroids from South India. I Suborder Athecata. J. Mar. Biol. Assoc. India 5(1): 27-61.

Mammen, T.A. (1965a) On a collection of Hydroids from South India. II Suborder Thecata (excluding Family Plumulariidae), J. Mar. Biol. Assoc. India 7(1): 1-57.

Mammen, T.A. (1965b) On a collection of Hydroids from South India. III Family Plumulariidae. J. Mar. Biol. Assoc. India 7(1): 291-324.

Mergner, H. (1972) The influences of several ecological factors on the hydroid growth of some jamaican coral cays. Proc. Symp. Corals and Coral Reefs, 1969, C. Mukaden \& C. S. G. Pillai edits for the Mar. Biol. Assoc. India, pp.275-290.

Mergner, H. (1977) Hydroids as indicator species for ecological parameters in Caribbean and Red Sea
Coral reefs. Proc. Int. Coral Reef Symp. Miami 1: 119-125

Mergner, H. \& Wedler, E. (1977) Uber die Hydroidpolypenfauna des Roten Meeres und seiner Ausgänge. Meteor Forsch.-Ergebnisse 24: $1-32$.

Migotto, A.E. (1996) Benthic shallow-water hydroids (Cnidaria, Hydrozoa) of the coast of São Sebastião, SP, Brazil, including a check list of Brazilian hydroids. Zool. Verhand 306: 1-125.

Millard, N.A.H. (1975) Monograph of the Hydroida of Southern Africa. Ann. S. Afr. Mus. 68: 1-513.

Millard, N.A.H. (1978) The geographical distribution of southern african hydroids. Ann. S. Afr. Mus. 74(6); 159-200.

Pennycuik, P.R. (1959) Faunistic records from Queensland. Part V Marine and brackish water hydroids. Pap. Dept. Zool. Univ. Queensland 1(6): 141-210.

Pichon, M. (1978) Recherches sur les peuplements à dominance d'anthozoaires dans les récifs coralliens de Tuléar (Madagascar). Atoll Res. Bull. 222: $1-447$.

Rédier, L. (1966) Hydraires et Bryozoaires. Cahiers du Pacifique 9: 77-122.

Rédier, L. (1971) Recherches sur les Hydraires et les Bryozoaires de la Polynésie française. Cahiers $d u$ Pacifique 15: 136-162.

Schuchert, P. (1996) The Marine Fauna of New Zealand: Athecate Hydroids and their Medusae (Cnidaria:Hydrozoa). New Zealand Oceanographic Institute Memoir 106: 159pp.

Vervoort, W. (1968) Report on a collection of Hydroida from the Caribbean region, including an annotated checklist of Carribean hydroids. Zool. Verh. Leiden (92): 1-124.

Vervoort, W. \& Vasseur, P. (1977) Hydroids from french Polynesia with notes on distribution and ecology. Zool. Verh. Leiden 159: 1-98.

Watson, J. (1996) Distribution and biogeographic relationship of the Hydroid fauna of the Australian West coast: a preliminary account. Sci. Mar: 60: $75-83$.

Watson, J. (1997) The hydroid fauna of the Houtman Abrolhos Islands, Western Australia. In: Wells, F.E., Ed., The Marine Flora and Fauna of the Houtman Abrolhos Islands, Western Australia. pp. 503-546.

Wedler, E. \& Larson R. (1986) Athecates hydroids from Puerto Rico and the Virgin Islands. Stud. Neotrop. Fauna Environ. 21(1-2): 69-101. 